\title{
COUNTERPRODUCTIVE WORK BEHAVIOR IN AIR TRANSPORTATION ORGANIZATIONS: A STUDY ON AIRLINE CABIN SERVICES
}

\author{
Research Asist. K. Gülnaz BÜLBÜL* \\ Anadolu University, Faculty of Aeronautics and Astronautics, (kgbulbul@anadolu.edu.tr) \\ Asistant Prof. Nalan ERGÜN \\ Anadolu University, Faculty of Aeronautics and Astronautics,(nergun@anadolu.edu.tr)
}

\begin{abstract}
The primary objective of this study is to identify the dimensions of CWB perceived by cabin crew, while the secondary objective is to determine the relationship between the perception of these dimensions and demographics. A research was conducted with the data gathered from 152 cabin crew in a mid-sized airline company via survey. As a result of the study, six dimensions, namely, Unsafe Behavior, Violating Service Standards and Rules, Violence against Other Crew Members, Misuse of Time and Resources, Property Misuse, and Violence Against Passengers were identified and analyzed. Non-parametric tests showed that 'Violating Service Standards and Rules' dimension relates with demographics the strongest.
\end{abstract}

Keywords: Organizational Behavior, Counterproductive Work Behavior, Airline, Cabin Services, Cabin Crew.

\section{HAVA TAŞIMACILIĞI ORGANIZASYONUNDA TERS ETKILİ ÇALIŞMA DAVRANIŞI: HAVA YOLU KABIN HIZMETLERİ ÜZERINE BİR ARAŞTIRMA}

\section{ÖZET}

Bu çalışmanın birincil amacı, kabin görevlilerinin algıladıkları Üretkenlik Karşıtı Davranışların (ÜKD) boyutlarını belirlemektir. İkincil amaç ise demografik faktörlerle ÜKD' oluşturan boyutların algısı arasındaki ilişkinin tespit edilmesidir. Orta ölçekli bir havayolu işletmesinde yapılan uygulamada 152 katılımcıdan elde edilen anket verileriyle analizler yapılmıştır. Analizler neticesinde ÜKD'ı oluşturan boyutlar olarak; Emniyeti Tehdit Eden, Hizmet Standart ve Kurallarını İhlal Eden, Ekip İçi Şiddete Dayalı, Zaman ve Kaynak İsrafına Dayalı, Mülke Zarar İçerikli, Yolcuya Yönelik Şiddete Dayalı Davranışlar ortaya çıkmıştır. Söz. konusu altı boyut üzerinden parametrik olmayan testler yapılmıştır. Demografik faktörler ile Hizmet Standart ve Kurallarını Íhlal Eden Davranışlar boyutu arasında en güçlü ilişki ortaya konulmuştur.

Anahtar Kelimeler: Örgütsel Davranış, Üretkenlik Karşıtı Davranışlar, Havayolu, Kabin Hizmetleri, Kabin Ekibi.

\footnotetext{
* Corresponding author
}

www.ijmeb.org ISSN:2147-9208 E-ISSN:2147-9194

http://dx.doi.org/10.17130/ijmeb.2017228691

Received: 03/11/2016, Accepted: 07/03/2017 


\section{Introduction}

In any organization, each individual displays idiosyncratic behavior patterns. The behavior of an individual can be supportive of the efficiency and productivity of an organization as well as being at odds with the organization's main goals. The management of organizational behavior so as to make it support organizational interests is an important factor in becoming a successful organization. Thus, determining and defining harmful behavior for an organization is crucial.

Individuals in an organization tend to intentionally or unintentionally behave in a way that contradicts the organization's goals when they are unsatisfied with the work environment. Behavior that aims to do harm to other members of the organization or the organization itself is called 'counterproductive work behavior' (CWB) (Spector et al., 2006).

CWB can have very important negative consequences when it occurs in the air transportation industry. When the highly dynamic, service intensive structure of the airline industry is considered, the damage that CWB can cause increases dramatically. Since service products are consumed at the same time as they are produced, it is impossible to undo the harm that is caused during the production process. Even a very minor disruption occurring at any point of the transportation process may affect the entire system and cause unwanted outcomes.

Airline cabin service is one of the most important components of air transportation activity. Cabin attendants are the employees of an airline and they have the longest interaction with passengers, giving the main service that the passengers pay for. Therefore, they have a direct effect on passenger perception of service quality and satisfaction. In addition, they play a vital role in the provision/maintenance of flight safety and security. When this crucial role and the responsibilities of cabin attendants are considered, the results of attendants' CWB can be calculated. The purpose of this study is to identify the CWB that are perceived by cabin crew in order to contribute to the enhancement of airline's flight safety, security and service quality. With respect to the fact mentioned above, the objective of this study is to identify the dimensions of the perceived CWB.

Also it is important to determine the relationship between perception of these dimensions and demographics factors in order to answer whether the demographics that are ascendants of CWB and the differing perceptions based on demographics correlate or not.

As mentioned above it is important to identify and classify CWB in order to recognize and manage them. Accordingly three main objectives of this study is;

- Identifying the CWB that are perceived by cabin crew.

- Classify the identified CWB under certain dimensions.

- Determine the relationship between perception of these dimensions and demographics factors. 


\section{Literature Review}

\subsection{CWB}

CWB is a research topic that has been drawing more and more attention since the 1990s. Before the 1990s CWB was not addressed as a specific concept and was covered under various terms such as theft, sabotage, withdrawal, and absenteeism.

Conducting a seminal study in this area, Robinson \& Bennet (1995) define CWB as norm-violating behavior that threatens the welfare of an organization and its members. Giacalone \& Greenberg (1997) who used the term anti-social behavior, define this behavior as behavior that do harm or intend to harm an organization, employees or shareholders. Under the term workplace aggression, Baron \& Neuman (1996) define CWB as individual behavior that aims to harm organization, former or current coworkers. Sackett \& Devore (2005) defined CWB as any intentional behavior on the part of an organization member viewed by the organization as contrary to its legitimate interest. Marcus (2002), using the term workplace counterproductivity, included behavior that obviously has no benefits, besides mentioning the harmful aspects of such behavior.

As commonly mentioned in the literature, CWB focuses on the behavior itself rather than the results. Behavior that harms an organization can be intentional or unintentional. CWB only concerns the intentional harmful behavior. Both an organization and individuals can be the target of CWB. The latter involves all individuals that take part in the production process. In the service industry, the costumer also takes part in this process. For this reason, when investigating CWB in the service industry it is reasonable to involve costumers as targets.

When all these approaches are considered, CWB can be defined as intentional behavior that is aimed at a member of an organization or the organization as a whole, contradicting organizational benefits and thus causing loss of motivation, and resulting in lower work performance or behavior that obviously does not bring any benefit.

\subsection{Classification of CWB}

Even though there was no holistic approach until the 1990s, the first systematic approach to this topic was a study published in 1983 by Hollinger and Clark. Hollinger and Clark mention two types of CWB: The first one is property deviance, which encompasses misuse of property, theft and violation of privileges. The second one is production deviance, which includes behavior that violates work norms. In 1995, Robinson and Bennett suggested a different approach by stating that the studies of Hollinger and Clark did not include interpersonal behavior. Working on this approach, Robinson and Bennett propose a twodimensional solution. In the first dimension of the structure, an inter-individuality factor is included in the organizational factor of Hollinger and Clark's model. Besides contributing to the first dimension, Robinson and Bennett define a second dimension, which concerns the magnitude of the harm given. They classify the harm given as either minor or serious. This two-dimensional structure introduces four categories; organizational-serious, organizationalminor, interpersonal-serious and interpersonal-minor. Gruys \& Sackett (2003) also propose a two-dimensional structure. The first dimension, which corresponds to the first dimension of 
Robinson and Bennett's structure, is interpersonal-organizational. The structure differentiates the second dimension, which concerns task-relevance. Although there are different approaches in literature in classification of CWB, this study is based on 11 dimensions under the four-class structure proposed by Gruys and Sackett, considering its relevance to our field of study. These dimensions are as follows:

1. Theft and related behavior (theft of cash or property; giving away goods or services; misuse of employee discount).

2. Destruction of property (defacing, damaging, or destroying property; sabotaging production);

3. Misuse of information (revealing confidential information; falsifying records).

4. Misuse of time and resources (wasting time, altering time card, conducting personal business during work time).

5. Unsafe behavior (failure to follow safety procedures; failure to learn safety procedures).

6. Poor attendance (unexcused absence or tardiness; misusing sick leave).

7. Poor quality work (intentionally slow or sloppy work).

8. Alcohol use (alcohol use on the job; coming to work under the influence of alcohol).

9. Drug use (possessing, using, or selling drugs at work).

10. Inappropriate verbal actions (arguing with customers; verbally harassing co-workers).

11. Inappropriate physical actions (physically attacking co-workers; physical sexual advances toward co-workers).

\subsection{Antecedents of CWB}

In the scope of this study, the antecedents of CWB are covered in two main categories as internal and external antecedents. The former refers to antecedents that are related to the individual, while the latter is about the factors that are related to the work environment.

\subsubsection{External Antecedents}

External antecedents are organization-related factors that trigger CWB rather than individual characteristics. Those can be grouped under five main topics as job characteristics, work group characteristics, control systems, organizational justice, and physical structure of organization.

It is claimed that a job with low meaningfulness and low responsibility can be linked to the likelihood of engaging CWB (Sackett \& DeVore, 2005). Low responsibility and low meaningfulness may prevent an individual from improving organizational commitment, which may trigger CWB.

Besides job characteristics, work group characteristics can also have great influence on an individual's behavior. Schneider's Attraction-Selection-Attrition Theory can be used to explain the effect of work group on CWB. According to this theory, individuals will be attracted to, and selected into work groups with which they share the attitudes while the others will stay 
out of the group. Moreover, encouragement and provocation may trigger CWB. In work groups that are highly engaged with CWB, other members of the group may be forced to behave according to the group's course of action. Norm-violating behavior may encourage employees in absenteeism, theft, or concealing mistakes (Sackett \& DeVore, 2005).

Another external antecedent that is mentioned by Griffin et. al. (2002) and Sackett \& DeVore (2005) is control systems. Although control systems do not completely prevent occurrence of CWB, they can be considered as intimidating precautions. In organizations that have weak inspection and social control, CWBs like absenteeism and consumption of alcohol are more likely to be engaged (Sackett \& DeVore, 2005). On the other hand, rigid control mechanisms have the risk to cause CWB by creating a highly oppressive environment. Employees may exhibit dishonest behavior in order to avoid the possibility of getting caught by control systems. Blaming another coworker to cover a mistake, not reporting an important incident are some examples for dishonest behavior that may occur because of the fear of the control systems.

Organizational justice is another factor that has an effect on CWB, which Sackett and DeVore (2005) underlined differently from other studies. Perception of injustice in an organization is claimed to be a trigger for CWB. While building their perception of justice, employees tend to compare their reward for their work with other coworkers. When there is an inequality in effort/reward ratio, individuals perceive unfairness. This sense of inequality may lead employees to CWB.

Physical structure of an organization can also have an effect on CWB. Yet, different from other external antecedents, it has an indirect effect. In large organizations, CWBs like working sloppy, absenteeism, and consumption of alcohol are highly common. This can be explained by low fear of getting caught and being punished, depending on the idea of deficiency of control mechanisms. In other words, physical structure of an organization induces other antecedents and control systems, which then trigger CWB. Another drawback of being in a large organization is having mostly formal relationships. Lack of informal relationships may cause lower motivation and belonging. In the case of low-level belonging, organizational commitment may underdeveloped, eliminating a very important factor that stands between employees and CWB (Sackett \& DeVore, 2005; Lau et. al., 2003).

\subsubsection{Internal Antecedents}

Internal antecedents are factors related to the individual that lead employees to engage in norm-violating behavior. Personality, job satisfaction, organizational commitment, perceived stress, attitudes and demographics are the main internal antecedents of CWB.

Personality is one of the main internal antecedents that have a direct relationship with CWB. According to Salgado \& Rumbo (1997), the big five personality traits are related with CWB. The first of these is Conscientiousness. Individuals with this trait are organized, systematic and punctual in nature. Accordingly, the relationship between this trait and CWB is negative. Employees that have high conscientiousness do not tend to engage in norm-violating behavior, as they are responsible and self-disciplined. In contrast to conscientiousness, neuroticism is a trait that has a positive relationship with CWB. Individuals that are neurotic are emotionally 
unstable, thus the rate of absenteeism, and not working up to certain standards are very high for this type of employees. Openness, being creative and open to new ideas, agreeableness, being affable, tolerant and sensitive, being extravert, being sociable and outgoing are traits that have both negative and positive relationship with CWB. These traits can lead to good work relations resulting in high organizational belonging and motivation. On the contrary, being sociable and agreeable may cause an employee to adopt CWB in the work group more easily. Moreover, being open to new ideas may cause some unsafe behavior. Creativity of an individual may encourage him/her to violate the procedures (Spector, 2011 \& Lau et. al, 2003).

Besides the big five personality traits, locus of control, which can be defined as a generalized disposition to assign responsibility for both positive and negative outcomes to either environmental causes (external locus of control) or internal causes (internal locus of control), is another personality trait that affects CWB (Martinko et. al., 2002). Martinko et. al. claim that individuals with external locus of control are more likely to exhibit CWB. Since individuals with external locus of control do not take responsibility for results, they are more comfortable with engaging in CWB. Honesty is another personality trait that keeps employees from behaving unethically (Robinson \& Bennet, 2002). Finally, Machiavellianism can be linked to CWB. Machiavellianists are individuals that manipulate and deceive others, despise ethical and moral values, and are capable of doing anything for success. As can be understood from this self-explanatory definition, this type of employees are more likely to violate organizational norms in order to look out for themselves and reach their goals (Rogojan, 2009).

In addition to personal traits, job satisfaction is another factor that is linked to CWB. Employees with low satisfaction also have low job performance, making them more likely to exhibit theft, withdrawal, absenteeism and sabotage (Ostroffs, 1992). Hollinger and Clark (1983) determined that unsatisfied employees tend to engage with theft. Besides, unsatisfied employees are prone to use drugs in order to fill in time (Mongione \& Quinn, 1975).

The level of job satisfaction is also has an important effect on organizational commitment. Satisfaction is a prerequisite for commitment. Employees with high organizational commitment are less likely to exhibit CWB than those with low commitment (Marcus, 2002).

Another internal antecedent that triggers CWB is perceived stress. It is not possible to single out and consider stress on its own. Personality is an important factor that affects perception of stress. Neurotic individuals are expected to have a low stress ceiling while emotionally stable individuals have a high ceiling. Employees who perceive work stress are likely to exhibit lower performance and higher absenteeism. A high stress level may also cause some disruptions in work processes (Lau et. al. 2003).

Based on norms and values, ethics is a phenomenon that determines an individual's attitude. As antecedents of CWB and addressing the norms and values that have an effect on individual's perception of morality, attitudes can cause an individual to exhibit a behavior that is commonly labeled as wrong by society. A person who does not consider theft unethical is more likely to exhibit this behavior (Greenberg, 2002).

The last factor that can be linked to CWB is demographics. Gender, age, tenure in a company or profession, number of family members and level of income are some of the 
demographics that are related with CWB. Long tenure in the company may cause an employee to get accustomed to norm-violating behavior in the company. For an individual who stays in the same place for a long time, some behavior that used to be unethical may become acceptable in time. Similarly, employees with short tenure may engage in CWB as a result of underdeveloped organizational commitment. Findings on age and tenure in the profession are not clear. Gender and having a big family is directly related to absenteeism. Women who are part of a crowded family tend to be late and show absenteeism. Finally, as for the level of income, employees with low-income are found to be more likely to use alcohol and drugs (Rogojan, 2009; Lau et. al. 2003; Baron \& Neuman 1996).

\section{CWB in Cabin Services}

Air transportation is a part of the service industry. Service activities involve face-to-face communication. In the air transportation field, the cabin crew employee group has the longest interaction with passengers. Thus, they have a crucial importance on the perception of service quality. CWB may cause the cabin crew to have low job motivation and performance, which directly affects the quality of service. Furthermore, cabin service involves teamwork, so it is not possible for a cabin crew member to work individually. For these two main reasons, CWB displayed by cabin crew can cause deviations in the service processes resulting in a decrease in airline efficiency and productivity.

Controlling environmental conditions inside the cabin, sustaining comfort, and providing a clean and relaxing cabin environment are the responsibilities of the cabin crew. In addition, maintaining flight safety is also an important responsibility of cabin crew. In emergencies that may occur during the flight, such as health issues (where there is no doctor), the cabin crew are authorized to intervene (Ergün, 2008). For air transportation, the cabin crew play an important role in both providing/maintaining passenger satisfaction and ensuring flight safety and security.

Because the cabin crew are responsible for all the duties listed above, CWB exhibited by them may have serious consequences such as low customer satisfaction, diminished passenger flight comfort and decreased security.

\section{Research Design And Methodology}

\subsection{Instrument}

The data were collected via survey. The survey was prepared with reference to a literature review and the scale in the article 'Investigating the Dimensionality of Counterproductive Work Behavior' by Melissa L. Gruys and Paul R. Sackett.

Due to the subject of the study, in order to get more realistic responses, the survey is built on the basis of attributive projection theory. Projection is one of the defense mechanisms that were introduced by Freud. Attributive projection is the most common type of projection. Thus there is a wide range of research on this topic (Chalus, 1978). According to this theory, individuals tend to seek their own behavior in others. In other words, they are likely to protect and defend themselves by projecting their deviations to others (Baumeister, 1998). Thus, the statements in Gruys and Sackett's scale were revised to measure perception rather than behavior 
itself, which called for the collection of data not on self-evaluation but on the evaluation of coworkers.

As it has already been mentioned in the classification of CWB, Gruys and Sackett proposed an 11-dimensional scale. However, in order to ensure the compatibility of the scale with the cabin crew, some statements were removed while some new expressions were added. For instance, the absenteeism dimension was eliminated since it is impossible for a cabin crew member to leave a flight early or to "no-show" for a flight duty since it is a direct reason for suspension. In addition, the statements were arranged according to cabin processes. The statements were predicted to be collected under nine dimensions, however, upon data analysis the statements were revised and more accurately grouped within six dimensions. In order to increase the validity of the scale, the interview was conducted with the airline managers. After the interview, some statements not approved by the airline were either eliminated or modified. The scale was then implemented with ten cabin crew members in order to guarantee the comprehensibility of the statements. Finally, a 40-statement scale structure was formed.

The survey is in two parts. The first part consists of demographic questions on age, marital status, educational level, title, tenure in the profession, tenure in the company, income level and being the only employed family member. The second part of the survey consists of 40 statements to measure the perception of CWB. Those 40 statement is expected to be under nine dimensions as; Theft and Related Behavior, Destruction of Property, Misuse of Information, Misuse of Time And Resources, Unsafe Behavior, Poor Quality Work, Alcohol Use, Inappropriate Verbal Actions and Inappropriate Physical Actions (Appendix 1). The scale used in the study is the Likert scale, of which ratings are as follows: Always=5, Very Often=4, Sometimes $=3$, Rarely $=2$, Never $=1$.

\subsection{Participants}

The research was conducted on the cabin crew of a middle-sized airline company. Both preparation and distribution process of the survey was carried out with the corporation of the human resources department of the airline. Within this context the survey was delivered to all 713 cabin crew of the airline via the intranet of the company.

152 usable responses were reviewed. This number of 152 participants is sufficient to conduct a factor analysis on a 40-item scale. ${ }^{1}$

The distribution of the participants according to demographic variables can be seen in Table 1.

1 Having 3 participants for each statement was found to be sufficient to conduct factor analysis. 
Table 1: Distribution of the Participants

\begin{tabular}{|c|c|}
\hline Demographic $(n=152)$ & $\%(n)$ \\
\hline \multicolumn{2}{|l|}{ Age } \\
\hline $20-25$ & $1,32 \%(2)$ \\
\hline $26-30$ & $15,13 \%(23)$ \\
\hline $31-35$ & $34,21 \%(52)$ \\
\hline $36-40$ & $32,24 \%(49)$ \\
\hline$>40$ & $17,11 \%(26)$ \\
\hline \multicolumn{2}{|l|}{ Gender } \\
\hline Female & $69,74 \%(106)$ \\
\hline Male & $30,26 \%(46)$ \\
\hline \multicolumn{2}{|l|}{ Educational Level } \\
\hline High School & $25,66 \%(39)$ \\
\hline Associate Degree & $19,08 \%(29)$ \\
\hline Under Graduate & $50,00 \%(76)$ \\
\hline Graduate & $5,26 \%(8)$ \\
\hline \multicolumn{2}{|l|}{ Title } \\
\hline Cabin Crew & $24,50 \%(37)$ \\
\hline Senior Cabin Crew & $75,50 \%(114)$ \\
\hline \multicolumn{2}{|l|}{ Missing } \\
\hline \multicolumn{2}{|l|}{ Tenure in the Profession } \\
\hline$<1$ year & $0 \%(0)$ \\
\hline $1-5$ years & $11,18 \%(17)$ \\
\hline $6-10$ years & $38,16 \%(58)$ \\
\hline $11-15$ years & $28,29 \%(43)$ \\
\hline$>15$ years & $22,37 \%(34)$ \\
\hline \multicolumn{2}{|l|}{ Tenure in the Company } \\
\hline$<1$ year & $0,66 \%(1)$ \\
\hline $1-5$ years & $18,42 \%(28)$ \\
\hline $6-10$ years & $40,13 \%(61)$ \\
\hline $11-15$ years & $22,37 \%(34)$ \\
\hline$>15$ years & $18,42 \%(28)$ \\
\hline \multicolumn{2}{|l|}{ Income Level } \\
\hline $1000-2000 \mathrm{TL}$ & $5,26 \%(8)$ \\
\hline $2001-3000 \mathrm{TL}$ & $42,76 \%(65)$ \\
\hline $3000-4000 \mathrm{TL}$ & $32,24 \%(49)$ \\
\hline$>4000 \mathrm{TL}$ & $19,74 \%(30)$ \\
\hline \multicolumn{2}{|c|}{$\begin{array}{l}\text { Being the Only Working Member of the } \\
\text { Family }\end{array}$} \\
\hline Yes & $80,26 \%(122)$ \\
\hline No & $19,74 \%(30)$ \\
\hline
\end{tabular}




\section{Analysis And Findings}

A reliability analysis was conducted before other analysis. In reliability analysis the Cronbach's Alpha was found to be 0.775 , meaning that the scale used was fairly reliable (Tabachnick \& Fidel, 2013).

Even though the scale was drawn from the literature, since all the statements were modified with respect to the profession, some new statements were added and some were deleted, and rather than a confirmatory factor analysis, an exploratory factor analysis was conducted.

\subsection{Exploratory Factor Analysis}

Kaiser-Meyer-Olkin (KMO) and Bartlett tests were conducted in order to determine whether the statements were convenient for factor analysis. Since the KMO value equals $0,652$ ( $>0,60)$, results gathered from the factor analysis were usable and useful (Pallant, 2001). There was a significant high-level relationship between the variables as a result of the Bartlett Sphericity test, meaning that the data were available for a factor analysis $\left(\mathrm{X}^{2}: 1055,813\right.$, sd:190 $\mathrm{p}<0,05)$.

As a result of the factor analysis, the number of statements dropped from 40 to 20 , falling under six factors (Appendix 1). The variances explained by each of the six factors can be seen in Table 2 .

Table 2: Variances Explained by Each of the Six Factors

\begin{tabular}{|c|c|c|c|c|c|c|}
\hline \multirow[b]{2}{*}{ Factor } & \multicolumn{3}{|c|}{ Initial Eigenvalues } & \multicolumn{3}{|c|}{ Total Load Factors (Rotated) } \\
\hline & Total & $\begin{array}{c}\text { \%Variance } \\
\text { Explained }\end{array}$ & Cummulative & Total & $\begin{array}{c}\% \\
\text { Varience } \\
\text { Explained } \\
\end{array}$ & Cummulative \\
\hline $\begin{array}{l}\text { Unsafe } \\
\text { Behavior }\end{array}$ & 3,63 & 18,13 & 18,13 & 2,57 & 12,86 & 12,86 \\
\hline $\begin{array}{l}\text { Violating } \\
\text { Service } \\
\text { Standards } \\
\text { and Rules }\end{array}$ & 2,98 & 14,89 & 33,01 & 2,50 & 12,48 & 25,34 \\
\hline $\begin{array}{l}\text { Violence } \\
\text { Against } \\
\text { Other Crew } \\
\text { Members }\end{array}$ & 2,10 & 10,50 & 43,51 & 2,41 & 12,04 & 37,38 \\
\hline $\begin{array}{l}\text { Misuse of } \\
\text { Time and } \\
\text { Resources }\end{array}$ & 1,92 & 9,61 & 53,12 & 2,32 & 11,60 & 48,98 \\
\hline $\begin{array}{l}\text { Production } \\
\text { Deviance }\end{array}$ & 1,51 & 7,56 & 60,69 & 1,84 & 9,20 & 58,18 \\
\hline $\begin{array}{l}\text { Violence } \\
\text { Against } \\
\text { Passengers }\end{array}$ & 1,11 & 5,54 & 66,22 & 1,61 & 8,05 & 66,22 \\
\hline
\end{tabular}


The item 'Falsifying or even not filling flight documents', which was under 'Misuse of Information', -one of the nine dimensions in the literature- appears in the 'Unsafe Behavior' dimension due to the direct effect of information on flight safety. For example, if a defect noticed during a cabin check is not reported in technical reports, it directly endangers the flight safety.

The statements 'Intentionally failing to give a senior cabin crew important information.' and 'Lying to a crew member or a senior cabin crew to cover up a mistake.' appear in the 'Violating Service Standards and Rules' dimension. The main reason for this is that the flow of information directly affects the service quality in the cabin processes. The statement 'Intentionally destroying flight documents (i.e. costumer complaint forms)' is to determine the nature of customer complaints. This statement appears in 'Misuse of Time and Resources' dimension as this group of behavior prevents enhancements in service processes causing a waste of time and resources.

The statements, 'Intentionally performing service below acceptable standards' and 'Intentionally hindering service efficiency' under 'Low Service Quality' appear in the newly named factor 'Violating Service Standards and Rules'. 'Intentionally working slow or sloppy during cabin services.' is another statement that was analyzed under 'Low Service Quality'. This statement is found in the 'Misuse of Time and Resources' dimension, as time is one of the most important resources in cabin services.

The inappropriate physical actions and inappropriate verbal actions dimensions are grouped under violence and then are covered in two dimensions as 'Violence Against Other Crew Members' and 'Violence Against Passengers'.

'Theft and Related Behavior' and 'Alcohol Use' are eliminated during the factor analysis. The statements that were earlier predicted to form nine dimensions were later classified in six dimensions. Reliability analysis showed that each factor was reliable. Also each factor load were above 0.320 (Tabachnic \& Fidell, 2013).

\subsection{Perception Level of Each Dimension}

Minimum, maximum, average and standard deviations of these six dimensions are calculated (Table 3). 'Violating service standards and rules' identified to be the dimension with the highest average value, followed by 'Misuse of time and resources'. These two dimensions consists of relatively less deviant behavior, compared to other four dimensions. Thus this is an expected result. On the other hand, 'Violence Against Passengers' is the less observed dimension, since it consists of deviant behavior that directly target passengers with physical and verbal violence.

\subsection{Analysis on the Relationship Between the Perception of CWB and the Demographic Variables}

In order to determine whether there is a relationship between the perception of CWB and demographic variables, analyses that are mentioned below are conducted. As data concerning the demographics were not normally distributed, the Mann-Whitney U Test was applied to 
Table 3:Level of Perception of Each Dimension

\begin{tabular}{|lllll|}
\hline \multicolumn{1}{c}{ Dimensions } & Minimum & Maximum & Mean & $\begin{array}{c}\text { Std. } \\
\text { Deviation }\end{array}$ \\
\hline Unsafe Behavior & 1 & 2,75 & 1,30 & 0,36 \\
$\begin{array}{l}\text { Violating Service } \\
\text { Standards and Rules }\end{array}$ & 1 & 3 & 2,17 & 0,52 \\
$\begin{array}{l}\text { Violence Against Other } \\
\text { Crew Members }\end{array}$ & 1 & 3 & 1,59 & 0,53 \\
$\begin{array}{l}\text { Misuse of Time and } \\
\text { Resources }\end{array}$ & 1,2 & 2,8 & 1,91 & 0,34 \\
$\begin{array}{l}\text { Production Deviance } \\
\text { Violence Against }\end{array}$ & 1 & 2,5 & 1,31 & 0,40 \\
Passengers & 1 & 2,5 & 1,16 & 0,33 \\
\hline
\end{tabular}

determine the relationship among gender, titles, being the only employed family member, the demographics and the sub-dimensions of the perception of CWB.

In order to determine the relationship among age, educational level, tenure in the profession, tenure in the company, income levels from the demographics and the dimensions of the perception of CWB, the Kruskal Wallis Test was applied. This was because of the abnormal distribution and multi-independent variable structure of the demographics data.

\section{Relationship Between Unsafe Behavior and Demographic Variables}

It was determined that the perception of unsafe behavior was rated higher by senior cabin crew than the cabin crew (Median: Senior Cabin Crew (SC) $=1.25>(\mathrm{C})$ Cabin Crew $=1.00)^{2}$ This can be explained by the senior cabin crew's inspector role. The experience that comes with the title may also be an explanation for senior cabin crew members to have a higher perception of unsafe behavior. It was concluded that perception of unsafe behavior increases directly proportional to age up to 41 years old and older (Median: $30-=1.00<31-35=1.25,36$ $40=1.50$ and $41=1.25<36-40=1.25$ ). There is a decrease in perception in the group who are 41 years old or older. Since age was parallel to title this result was consistent. Earlier studies (Hacket, 1990) also found that long job tenure may cause employees to become more inured to norm-violating behavior, which supports the findings of the present study.

\section{Relationship Between Violating Service Standards and Rules and Demographic Variables}

'Perception of behavior which violates service standards and rules' is the dimension that exhibits a strong relationship with demographics. Gender, title, age, educational level, tenure in the profession, tenure in the company and income level are related to the perception of behavior

2 Since normal distribution was not observed in the demographics, the interpretation was based on the median values of the applied nonparametric analyses. 
Table 4: Relationship Between the CWB Dimensions and Demographics

\begin{tabular}{|c|c|c|c|c|c|c|c|c|}
\hline \multirow[b]{2}{*}{ Dimensions } & \multicolumn{8}{|c|}{ Demographics } \\
\hline & Gender & Title & $\begin{array}{l}\text { Being the } \\
\text { Only Working } \\
\text { Member of } \\
\text { the Family }\end{array}$ & Age & $\begin{array}{c}\text { Educational } \\
\text { Level }\end{array}$ & $\begin{array}{l}\text { Tenure in } \\
\text { the } \\
\text { Profession }\end{array}$ & $\begin{array}{l}\text { Tenure in } \\
\text { the } \\
\text { Company }\end{array}$ & $\begin{array}{l}\text { Income } \\
\text { Level }\end{array}$ \\
\hline Unsafe Behavior & 0,612 & $0,011^{*}$ & 0,649 & $0,001^{* *}$ & 0,333 & 0,119 & 0,097 & 0,104 \\
\hline $\begin{array}{l}\text { Violating Service } \\
\text { Standarts and Rules }\end{array}$ & $0,009^{*}$ & $0 * * *$ & 0,276 & $0,048^{*}$ & $0,011^{*}$ & $0,001^{* *}$ & $0,009^{* *}$ & $0,008^{* *}$ \\
\hline $\begin{array}{l}\text { Violance Against } \\
\text { Other Crew } \\
\text { Members }\end{array}$ & 0,655 & 0,613 & 0,07 & $0,045^{*}$ & 0,114 & 0,724 & 0,147 & 0,127 \\
\hline $\begin{array}{l}\text { Misuse of Time and } \\
\text { Resources }\end{array}$ & 0,728 & 0,51 & 0,669 & 0,832 & 0,122 & $0,039^{*}$ & $0,002^{* *}$ & 0,127 \\
\hline $\begin{array}{l}\text { Production } \\
\text { Deviance }\end{array}$ & $0 * * *$ & 0,257 & 0,695 & 0,118 & 0,629 & 0,756 & 0,521 & 0,327 \\
\hline $\begin{array}{l}\text { Violance Against } \\
\text { Passengers }\end{array}$ & $0,001^{* *}$ & 0,155 & 0,557 & $0,002^{* *}$ & $0,042^{*}$ & 0,073 & $0,015^{*}$ & $0,006^{* *}$ \\
\hline $\begin{array}{l}{ }^{*} \mathrm{p}<, 05 \\
{ }^{* *} \mathrm{p}<, 01 \\
{ }^{* * *} \mathrm{p}<, 001\end{array}$ & & & & & & & & \\
\hline
\end{tabular}

that violate service standards and rules. It is determined that the level of perception for this kind of behavior is higher in men (Median: Women $(\mathrm{W})=2.00<\operatorname{Men}(\mathrm{M})=2.25$ ). This result may be due to the imbalance between the number of male and female participants. It is difficult to determine the effect of gender on the perception of behavior violating service standards and rules. As with the perception of unsafe behavior, the senior cabin crew's perception was also higher for this dimension (Median: $\mathrm{SC}=1.75<\mathrm{C}=2.25$ ), which can be explained by experience and senior cabin crew being also an inspector. The effect of experience on perception was also parallel to the relationship between this dimension and tenure in the profession, as well as tenure in the company. The perception of the cabin crew who have 10 years or more experience in the profession had the highest level of perception (Median: $1-5=2.25,6-10=2.00<11$ $15=2.50,15+=2.00$ and $11-15>15+)$. The same relationship was also valid for tenure in the company (Median: $1-5=2.25,6-10=2.00<11-15=2.37,15+=2.12$ and $11-15>15+$ ). There is a positive correlation between age and perception until age 41 (Median: 31-35=2.37>30-=2.25, $36+=2.00)$. This result supports the finding on title. As mentioned earlier, there is a positive correlation between experience and perception; however, the decrease of perception after the age of 41 can again be explained by becoming inured to such behavior. The perception of behavior that violates service standards and rules is higher in high school graduates (Median: High school=2.5 $>$ High school or higher=2.00). This can be explained by the influence of one's 
behavior on his/her perception or feelings of self-inadequacy. The lower income level crew are those with the lowest level of perception (Median: 3000- $=2.00<3001-4000=2.5,4001+=2$ ). As income increases with the experience, this may also explain how experience affects perception.

\section{Relationship Between Violence Against Crew Members and Demographic Variables}

No strong relationship was found between demographic variables and the perception of violence against other crew members. It was determined that perception of those over the age of 41 was lower (Median: 36-40=1.67>41+=1.33). As they are the most experienced and with the highest status age group among the cabin crew, the staff in the 41+ age group are usually not exposed to violent behavior, so they may not perceive this kind of behavior.

\section{Relationship Between Misuse of Time and Resources and Demographic Variables}

Perception of the 'Misuse of Time And Resources' is correlated with both experience in the profession and tenure in the company. According to the results, the employees who are working in the same company (Median: 1-5, 15+=1.80<6-10=11-15=2.00) or in the same profession (Median: $1-5=1.60,15+1.8,<6-10=11-15=2.00$ ) for $6-10$ and $11-15$ years have higher perceptions of 'Misuse of Time And Resources'. Again, experience and acclimation can explain this. Cabin crew who are new to the industry may not have enough experience to perceive this type of behavior. On the other hand, those in the industry for over 15 years may have acclimated to them, resulting in a decrease in their perception.

\section{Relationship Between Property Deviance and Demographic Variables}

The perception of property deviance was found to be solely related with gender. The perception of men is higher than women (Median: $\mathrm{W}=1.00<\mathrm{M}=1.50$ ). However, since there is an imbalance between the number of female participants and male participants, this result may not be very reliable.

\section{Relationship Violence Against Passengers and Demographic Variables}

Perception of violence against passengers correlated with most of the demographics: gender, age, educational level, tenure in the company, and level of income. The perception of violence is greater in men, but again it is hard to make a conclusion due to the imbalance in the number of men and women (Mean: $M=1.30>\mathrm{W}=1.10$ ). Crew members who are 31-40 years old have a higher perception of violence against passengers (Mean: 30-=1.28, 31-35=1.08, $41+=1.07<30-=1.28,36-40=1.22$ ). Moreover, crew members with an associate's degree also have higher perception than others. It was also found that members who have been working in the company for 11-15 years perceive behavior in this dimension to a higher degree, which can be explained by acclimation. There is also a relationship between levels of income in this dimension but it is not significant.

\section{Conclusion and Suggestions}

Our hypothesis was supported by some demographics while by others it is rejected. Although a relationship between demographics and some dimensions is found, because cabin crews are mostly staffed with women, it's difficult to make a precise judgment on the effect of 
gender. 'Violating Service Standards and Rules' is the dimension that is most commonly related with demographics. This is followed by 'Violence Against Passengers'. The scale is designed to measure cabin crew perceptions and was tested within this study. In order to determine a more precise conclusion, it is necessary to test the scale in different companies. Reaching an adequate distribution in further studies will give the opportunity to come up with more exact conclusions on the effect of the gender.

Studies about CWB are commonly on identifying the rate that individuals directly exhibit those behavior. However this study, as being built on the basis of attributive projection theory, measures perception in order to get unbiased answers. Furthermore there is no other studies about CWB on airline industry. More accurate conclusions can be reached when the number of studies on CWB in cabin services increases.

As previously mentioned in the study, CWB can cause substantial tangible and intangible harm. For this reason it is very important to identify the CWB that cabin crew come across, and the root of those behavior in order to airlines to get precautions. This study focuses on the perception of CWB rather than measuring the occurrence rate of those behavior. As a result of the study it is identified that experience and title has an effect on perception. Therefore, it must be noted that airlines should consider the differences in perception and build a multi directional feedback mechanism that involves both the superiors and the subordinates, to detect CWB. Nevertheless in order to ensure that the feedbacks reflect the truth, an environment of trust should be build that cabin crew can freely express their problems about such behavior. Besides an inverse relation between work tenure and perception is identified. This result may be stemmed from, employees to get accustomed to CWB and perceiving them as ordinary. Thus regular educations must be organized in order to provide continuity of awareness of CWB.

\section{References}

Baron, R.A., \& Neuman, J. H. (1996). Workplace violence and workplace aggression: Evidence on their relative frequency and potential causes. Agressive Behavior, 161-173.

Baumeister, R.F., Dale, K., \& Sommer, K.L. (1998). Freudian defense mechanisms and empirical findings in modern social psychology: Reaction formation, projection, undoing, isolation, sublimation and denial. Journal of Personality, 66, 1081-1124.

Chalus, A. D. (1978). The mechanisms underlying attributive projection. Journal of Personality, 46 (2), 362-382.

Ergün, N. (2008). Kabin memurlarının kabin içi düşük hava kalitesi nedeniyle karşı karşıya kaldıkları sorunları. Kayseri VII. Havacılık Sempozyumu Bildiriler Kitabı, Kayseri, 120-122.

Giacalone, R.A., \& Greenberg, J. (1997). Antisocial behaviors in organizations. London: Sage Publications.

Greenberg, J. (2002). Who stole the money, and when? Individual and situational determinants of employee theft. Organizational Behaviour and Human Decision Processes, 89, 9851003 .

Griffn, R. W., Anne, A. O.-K., \& Collins, J. (2002). Dysfunctional work behaviors in organizations. Journal of Applied Psychology, 36-50. 
Gruys, M. L., \& Sackett, P. R. (2003). Investigating the dimensionality of counterproductive work behaviour. International Journal of Selection and Assesment, 30-42.

Hackett, R. D. (1990). Age, tenure, and employee absenteeism. Human Relations, 43(7), 601619.

Hollinger, R. C., \& Clark, J. P. (1983). Theft by employees. Lexington, MA: Lexington Books.

Lau, V. C., Au, W. T., \& Ho, J. M. (2003). A qualitative and quantitative review of antecendents of counterproductive behaviour in organizations. Journal of Business and Psychology, 73-90.

Mangione., T. W., \& Quinn, R. P. (1975). Job satisfaction, counterproductive behavior, and drug use at work. Journal of Applied Psychology, 114-116.

Marcus, B. (2002). Measuring counterproductivity: Development and initial validation of a German self-report questionnaire. International Journal Of Selection and Assesment, 18-35.

Martinko, M. J., Gundlach, M. J., \& Douglas, S. C. (2002). Toward an integrative theory of counterproductive workplace behavior: A causal reasoning perspective. International Journal of Selection and Assesment, 36-50.

Ostroff, C. (1992). The relationship between satisfaction, attitudes, and performance: An organization level analysis. Journal of Applied Psychology, 963-974.

Robinso, S. L., \& Bennet, R. J. (1995). Typology of deviant workplace behaviours: A multidimensional scaling study. The Academy of Managment Journal, 555-572.

Rogojan, P. T. (2009). Deviant workplace behavior in organizations: Antecedents, influences, and remedies. Magister der Sozial und Wirtschaftswissenschaften, Universitat Wien.

Sackett, P. R., \& DeVore, C. J. (2005). Counterproductive behaviors at work. In. N. Anderson, D. S. Ones, H. K. Sinangil, C. Viswesvaran (eds.), Handbook of Industrial, Work andOrganizational Psychology (pp. 145-164). London: Sage Publications .

Salgado, J. F., \& Rumbo, A. (1997). Personality and job performence in financial services managers. International Journal Of Selection and Assesment, 91-100.

Spector, P. E. (2011). The relationship of personality to counterproductive work behavior (CWB): An integration of perspectives. Human Resource Management Review, 342352.

Spector, P. E., Fox, S., Penney, L. M., Bruursema, K., Goh, A., \& Kessler, S. (2006). The dimensionality of counterproductivity: Are all counterproductive behaviors created equal? Journal of Vocational Behavior, 446-460.

Tabachnick, B. G., \& Fidell, L. S. (2013). Using multivariate statistics. 6th ed., Boston: Pearson. 


\section{APPENDIX 1}

The 11-dimension scale that Gruys and Sackett proposed was predicted to have nine dimensions within the study after adapting it to airline cabin processes. However, the factor analysis with 40 statements resulted in a six-dimension scale with 20 statements.

Statements under the dimension Theft and related behavior (six statements) and Alcohol use (three statements) were all eliminated. Statements under theft and related behavior may not be perceived as theft. For example, the statement "Giving away goods that are not free" might be perceived as a behavior that is beneficial to customer satisfaction. Conversely, some statements might be perceived as a crime and thus not answered correctly; such as the statement "Demanding payment for goods that are free" can have a perception of crime. The same case may also be valid for alcohol use, because the cabin crew undergo a review by control chiefs and pursers before flight.

Resting times are regulated and inspected by national and international authorities. For this reason, statements about resting times, under the "Misuse of Time and Resources" dimension, might not have been objectively considered, since it is uncommon behavior for cabin crew to "no show" for a flight without calling in sick. Statement 21 under this dimension might be considered as a security breach and would have been responded with hesitation.

Comparison of Dimensions Predicted Through Literature and Obtained by the Research

\begin{tabular}{|c|c|c|}
\hline \multicolumn{2}{|c|}{ Dimensions According to Literature } & \multirow{2}{*}{$\begin{array}{l}\text { Dimensions According to Research } \\
\text { Unsafe Behavior }\end{array}$} \\
\hline Theft and related behavior & Poor quality work & \\
\hline Statement 12 & Statement 9 & Statement 33 \\
\hline Statement 6 & Statement 25 & Statement 26 \\
\hline Statement 20 & Statement 30 & Statement 18 \\
\hline Statement 1 & Statement 4 & Statement 39 \\
\hline Statement 19 & Alcohol use & Violating Service Standards and Rules \\
\hline Statement 34 & Statement 17 & Statement 5 \\
\hline Destruction of property & Statement 8 & Statement 14 \\
\hline Statement 32 & Statement 23 & Statement 4 \\
\hline Statement 35 & Inappropriate verbal actions & Statement 9 \\
\hline Misuse of information & Statement 3 & Violence Against Other Crew Members \\
\hline Statement 39 & Statement 22 & Statement 11 \\
\hline Statement 28 & Statement 11 & Statement 36 \\
\hline Statement 27 & Statement 36 & Statement 29 \\
\hline Statement 5 & Statement 29 & Misuse of Time and Resources \\
\hline Statement 14 & Statement 15 & Statement 31 \\
\hline Misuse of time and resources & Statement 16 & Statement 37 \\
\hline Statement 31 & Inappropriate physical actions & Statement 30 \\
\hline Statement 2 & Statement 10 & Statement 28 \\
\hline Statement 13 & Statement 24 & Statement 13 \\
\hline Statement 37 & Statement 38 & Production Deviance \\
\hline Statement 21 & Statement 40 & Statement 32 \\
\hline Statement 7 & & Statement 35 \\
\hline Unsafe behavior & & Violence Against Passengers \\
\hline Statement 18 & & Statement 22 \\
\hline Statement 33 & & Statement 24 \\
\hline Statement 26 & & \\
\hline
\end{tabular}




\section{APPENDIX 2}

\section{The Adapted Scale Statements}

1. Giving away goods that are not free

2. Extending permitted resting time during flight

3. Arguing or fighting within crew

4. Intentionally hindering service efficiency

5. Intentionally failing to give a senior cabin crew important information

6. Taking away treats and other equipment that are for passengers

7. "No show" for a flight without calling in sick

8. Coming to a flight duty without obeying the resting hours

9. Intentionally performing service below acceptable standards

10. Physically attacking other crew members

11. Verbally abusing another crew members

12. Encouraging the use of treats and other equipment

13. Wasting time on cabin services

14. Lying to a crew member or a senior cabin crew to cover up a mistake

15. Having sexual conversations during flight

16. Arguing or fighting with a passenger

17. Coming to a flight duty under the influence of alcohol.

18. Endangering yourself by not following safety procedures

19. Demanding payment for goods that are free

20. Taking away a property of a passenger

21. Carrying personal mail/cargo in flight

22. A crew member Verbally abusing passengers

23. Consuming alcohol during flight

24. Physically attacking passengers

25. Intentionally making mistakes during work processes

26. Endangering passengers by not following safety procedures

27. Sharing private information about the airline with others who do not have authorization

28. Intentionally destroying flight documents (i.e. customer complaint forms)

29. Verbally abusing a senior cabin crew

30. Intentionally working slow or sloppy during cabin services

31. Conducting a personal business during flight

32. Intentionally harming or destroying a belonging of a passenger

33. Endangering crew members by not following safety procedures

34. Misusing employee privileges

35. Intentionally harming or destroying property of airline company

36. A senior cabin crew verbally abusing a crew member

37. Wasting in-flight catering materials and meals

38. Sexually harassing a crew member

39. Falsifying or even not filling flight documents

40. Sexually harassing a passenger 